Diabetologia (1993) 36:1191-1197

\title{
Post-hypoglycaemic hyperketonaemia does not contribute to brain metabolism during insulin-induced hypoglycaemia in humans
}

\author{
C. Fanelli, A. Di Vincenzo, F.Modarelli, M. Lepore, M. Ciofetta, L. Epifano, S. Pampanelli, P. Brunetti, G. B. Bolli \\ Dipartimento di Medicina Interna e Scienze Endocrine e Metaboliche, Università di Perugia, Perugia, Italy
}

\begin{abstract}
Summary. It is controversial as to whether ketone bodies are utilized by the human brain as a fuel alternative to glucose during hypoglycaemia. To clarify the issue, we studied 10 normal volunteers during an experimental hypoglycaemia closely mimicking the clinical hypoglycaemia of patients with Type 1 (insulin-dependent) diabetes mellitus or insulinoma. Hypoglycaemia was induced by a continuous infusion of insulin $\left(0.40 \mathrm{mU} \cdot \mathrm{kg}^{-1} \cdot \mathrm{min}^{-1}\right.$ for $8 \mathrm{~h}$, plasma insulin $\approx 180 \mathrm{pmol} / \mathrm{l})$ which decreased the plasma glucose concentration to approximately $3.1 \mathrm{mmol} / \mathrm{l}$ during the last $3 \mathrm{~h}$ of the studies. Subjects were studied on two occasions, i. e. spontaneous, counterregulatory-induced post-hypoglycaemic increase in 3 - $\beta$-hydroxybutyrate (from $\approx 0.2$ to $\approx 1.1 \mathrm{mmol} / 1$ at $8 \mathrm{~h}$ ), or prevention of post-hypoglycaemic hyperketonaemia (plasma $\beta$-hydroxybutyrate $\approx 0.1 \mathrm{mmol} / 1$ throughout the study) after administration of acipimox, a potent inhibitor of lipolysis. In the latter study, glucose was infused to match the hypoglycaemia observed in the former study. The glycaemic thresholds and overall responses of counterregulatory hor-
\end{abstract}

mones, symptoms (both autonomic and neuroglycopenic), and deterioration of cognitive function (psychomotor tests) were superimposable in the control study in which ketones increased spontaneously after onset of hypoglycaemic counterregulation, as compared to the study in which ketones were suppressed ( $p=\mathrm{NS})$. The fact that responses of counterregulatory hormones, symptoms and deterioration in cognitive function were not exaggerated when posthypoglycaemic hyperketonaemia was prevented, indicate that during hypoglycaemia, the counterregulatory-induced endogenous hyperketonaemia does not provide the human brain with an alternative substrate to glucose. Thus, it is concluded that during hypoglycaemia, endogenous hyperketonaemia does not contribute to brain metabolism and function.

Key words: Hypoglycaemia, counterregulatory hormones, symptoms, cognitive function, brain fuel, ketone bodies.
If the plasma glucose concentration acutely decreases below approximately $2.8 \mathrm{mmol} / \mathrm{l}$, the resulting neuroglycopenia impairs brain function [1]. This occurs despite the availability of alternative substrates that the brain can potentially oxidize, such as ketones, lactate and amino acids [2]. Thus, glucose is the major, if not the exclusive fuel for brain metabolism [3].

However, the fact that neuroglycopenia develops during hypoglycaemia despite the increased availability of substrates such as ketone bodies, after onset of counterregulation to hypoglycaemia [4], does not necessarily rule out a role for ketones as brain fuel during hypoglycaemia. One might hypothesize that neuroglycopenia could result in an earlier and/or more severe impairment in brain function if ketones had not increased in plasma during hypoglycaemia.

Although it has been demonstrated that the brain predominantly utilizes ketones during prolonged fasting in man [5], and even in acute conditions in animals [6,7], it is controversial as to whether ketones contribute to brain metabolism during acute, insulin-induced hypoglycaemia in humans. Frolund et al. [8] found no effect of a ketone infusion during hypoglycaemia. In contrast, Amiel et al. [9] reported evidence of utilization by the brain of ketones infused during insulin-induced hypoglycaemia. If ketones were fuel for the brain during hypoglycaemia as the study of Amiel et al. [9] indicates, then the rebound increase in plasma ketones during hypoglycaemia mimicking the clinical situation [4], should provide, at least in part, an alternative substrate for the brain. A physiological approach to test this hypothesis, is to establish if brain-mediated responses to hypoglycaemia are more pronounced when the endogenous hyperketonaemia in response to hypoglycaemia is prevented.

The present studies were undertaken to test the hypothesis that the spontaneous rebound increase in plasma 
ketones during acute, insulin-induced hypoglycaemia contributes to brain metabolism and function. To investigate this, the counterregulatory hormone responses, symptoms, and deterioration of cognitive function in acute, insulin-induced hypoglycaemia were studied under two conditions, i.e. spontaneous increase in plasma ketones after counterregulation, as well as prevention of hyperketonaemia after administration of acipimox to block lipolysis [10].

\section{Subjects and methods}

Subjects. Informed consent was obtained from 10 healthy volunteers (five males and five females) aged $24 \pm 1$ years, with a body mass index of $23.7 \pm 1.0 \mathrm{~kg} / \mathrm{m}^{2}$, and with no family history of diabetes or other endocrine diseases. Each subject was studied on two different occasions. With the exception of one subject who was restudied after 1 week, the remaining subjects were restudied after 3-4 weeks. For 3 days before the studies all subjects consumed a weight-maintenance diet containing at least $250 \mathrm{~g}$ carbohydrate.

Protocol. Institutional Review Board approval was obtained for these studies. All subjects were admitted to the Clinical Research Centre of the Istituto di Medicina Interna e Scienze Endocrine e Metaboliche, University of Perugia, between 06.30 and 07.00 hours, after an overnight fast (10-12 h). They were placed on bed rest and maintained in the supine position throughout the experiments. To obtain arterialized-venous blood samples [11], a dorsal hand vein was cannulated in a retrograde position with a 21 -gauge butterfly needle, with the hand maintained at $60-65^{\circ} \mathrm{C}$ in a thermoregulated plexiglass box. An antecubital vein of the contralateral arm was cannulated with an 18-gauge catheter and used for the infusion of insulin and, when required, glucose ( $20 \%$ solution) by means of separate syringe pumps (Harvard Apparatus Co., Inc., The Ealing Co., South Natick, Mass., USA). Both forearm and venous lines were kept patent by infusion of $0.9 \% \mathrm{NaCl}$ by means of two separate peristaltic pumps (VM 8000 M; Vial Medical, St-Martin-Le-Vinoux, Grenoble, France), at a rate of $30 \mathrm{ml} / \mathrm{h}$.

In the first set of experiments (control study), to induce moderate hypoglycaemia, insulin (Actrapid HM IU-40; Novo Nordisk, Copenhagen, Denmark), diluted to $1 \mathrm{IU} / \mathrm{ml}$ in $100 \mathrm{ml}$ of $0.9 \% \mathrm{NaCl}$ containing $2 \mathrm{ml}$ of the subject's blood, was intravenously infused at the rate of $0.40 \mathrm{mU} \cdot \mathrm{kg}^{-1} \cdot \mathrm{min}^{-1}$ for $8 \mathrm{~h}$ with a syringe pump (Harvard Apparatus Co.). This intravenous rate of insulin infusion was chosen to reproduce the mild hyperinsulinaemia observed in previous studies during subcutaneous insulin infusion in normal man [4], and to simulate the type of hypoglycaemia that may develop in diabetic patients undergoing intensive insulin therapy [12-15].

In the second set of experiments (henceforth referred to as blockade of ketogenesis study), insulin was infused as in the previous study, but acipimox (5-methyl-pyrazene-carboxylic acid 4-oxide, Olbetam; Farmitalia Carlo Erba, Milan, Italy) (250 mg orally) was given at $60 \mathrm{~min}$, and again at $240 \mathrm{~min}$ to block lipolysis. The sequence of studies was not randomized, neither were the studies double blind. Because we anticipated from a previous study [10] that suppression of lipolysis would result in impaired glucose counterregulation, glucose was infused when needed to prevent more severe hypoglycaemia and to maintain plasma glucose concentration at the values observed in the control study, based on plasma glucose concentration measured every $2.5-5 \mathrm{~min}$, as previously reported $[4,10]$. This enabled us to avoid the confounding effects of lower plasma glucose concentrations in the blockade of ketogenesis study as compared to the control study, to prevent greater counterregulatory hormone responses because of severe hypoglycaemia, and also to avoid the discomforts and potential risks of severe hypoglycaemia.

Arterialized-venous blood samples were drawn every $30 \mathrm{~min}$ from -30 to $480 \mathrm{~min}$ for determination of glucoregulatory hormones and substrates. A semiquantitative symptom questionnaire was compiled every $30 \mathrm{~min}$. Subjects scored from 0 (none) to 5 (severe) for each of the following symptoms: dizziness, tingling, blurred vision, difficulty in thinking, faintness, anxiety, palpitations, hunger, sweating, irritability, or tremor. In accordance with previous classifications $[1,16-18]$, the first five symptoms were considered neuroglycopenic and the last six were considered autonomic. The sum of each of these constituted the symptom score. In addition, at baseline and at 1 -h intervals thereafter, the following standard cognitive tests were compiled: trail-making part B, verbal fluency, interference subtest from the Stroop test, simple and choice visual reaction time, word and colour subtest from the Stroop test, digit vigilance test, trail-making part $\mathrm{A}$, verbal memory test and forward and backward digit span, as previously described [1]. On the evening before the study, the subjects extensively practiced each test. For the actual study, nine alternate forms were prepared. Subjects were not informed of their plasma glucose during the studies.

Analyses. Blood samples were collected at 30 -min intervals and assayed for glucose (Beckman Glucose Analyzer, Beckman Instruments, Fullerton, Calif., USA), insulin, C-peptide, cortisol, growth hormone, adrenaline and noradrenaline by previously described assays [19]. Glucagon was measured by a radioenzymatic assay using a commercially available kit (ICN, Biomedical, Inc., Costa Mesa, Calif., USA). Plasma non-esterified fatty acids (NEFA) were measured by an enzymatic colorimetric method (Wako NEFA C test kit; Wako Chemicals GmbH, Neuss, Germany), and 3- $\beta$-hydroxybutyrate, glycerol, alanine and lactate by a previously described method [20].

\section{Statistical analysis}

Data in text and figures are given as mean \pm SEM, and the statistical significance was evaluated using analysis of variance corrected for repeated measures [21]. A $p$ value less than 0.05 was considered significant. Glycaemic threshold for a given parameter was defined as the plasma glucose concentration at which the parameter first exceeded the $95 \%$ confidence limit observed for changes in that parameter at baseline (euglycaemia). Because of differences in units of treatment, results of cognitive tests were transformed to z-scores (individual value minus mean divided by standard deviation) [21] to permit their summation to obtain one unitless value for evaluation [1]. A commercially available software package (CSS, Stasoft, Tulsa, Okla., USA) was used for statistical analysis.

\section{Results}

\section{Plasma insulin and C-peptide concentrations}

Plasma insulin concentrations increased approximately 3.5 -fold during the $480 \mathrm{~min}$ insulin infusion in the control (from $49 \pm 7$ to $181 \pm 12 \mathrm{pmol} / \mathrm{l}$ ) and suppression of ketogenesis experiments (from $55 \pm 5 \mathrm{pmol} / \mathrm{l}$ to $178 \pm 14 \mathrm{pmol} / \mathrm{l})(p=\mathrm{NS})$. Plasma C-peptide was similarly suppressed on both occasions (data not shown).

\section{Plasma glucose, rates of glucose infusion, plasma NEFA, and 3- $\beta$-hydroxybutyrate (Fig. 1)}

In the control study, plasma glucose decreased progressively from $4.8 \pm 0.1 \mathrm{mmol} / \mathrm{l}$ to $3.1 \pm 0.1 \mathrm{mmol} / \mathrm{l}$ by 480 min. After initial suppression by insulin, plasma NEFA increased, and at 480 min they were greater than at 
baseline $(0.72 \pm 0.06 \mathrm{mmol} / 1$ vs $0.51 \pm 0.07 \mathrm{mmol} / \mathrm{l}$, $p<0.05$ ). Also plasma $3-\beta$-hydroxybutyrate was initially suppressed, but by the end of the study, had increased above baseline $(1.06 \pm 0.17 \mathrm{mmol} / 1$ vs $0.23 \pm 0.06 \mathrm{mmol} / 1$, $p<0.05$ ).

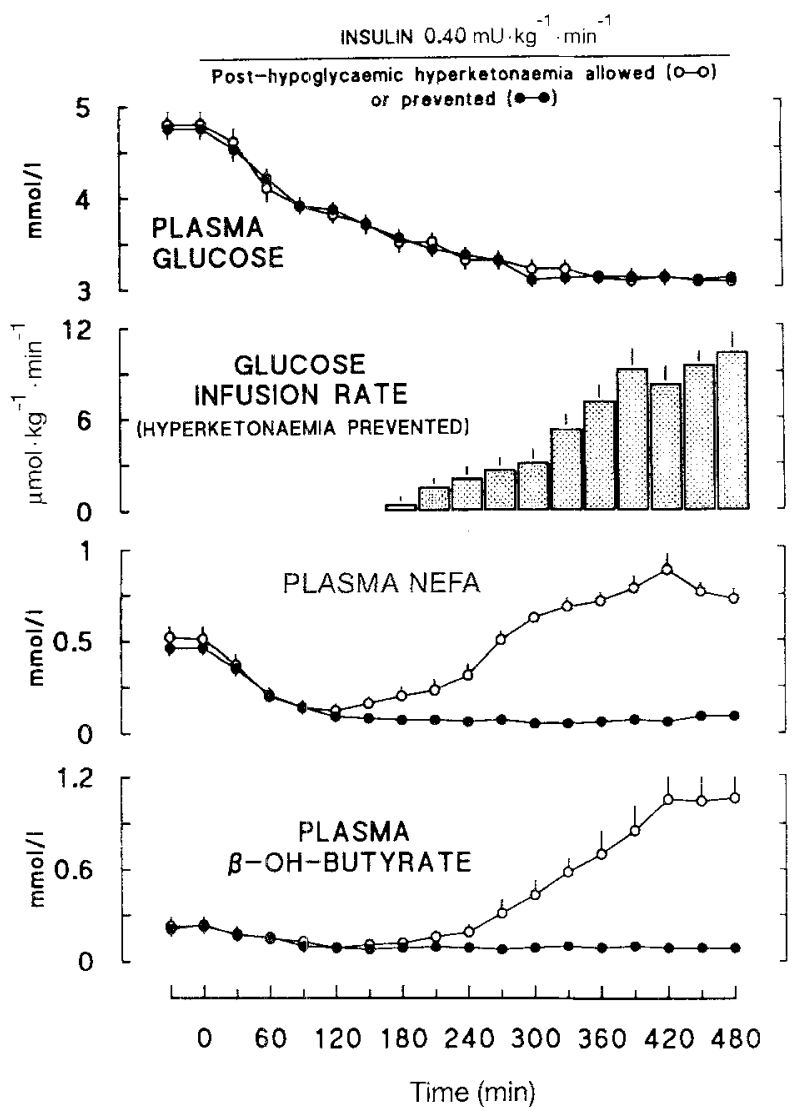

Fig. 1. Plasma glucose, non-esterified fatty acids (NEFA) and $\beta$-hydroxybutyrate concentrations during insulin-induced hypoglycaemia in the control study $(O)$ and in the blockade of ketogenesis study $(\bullet)$. The rates of glucose infusion needed in the blockade of ketogenesis study to maintain plasma glucose concentration at the level of the control study are also shown. Values shown are mean \pm $S E M . n=10$ normal subjects
When acipimox was administered to block ketogenesis, the decrease in plasma glucose was initially similar to that of the control study. However, after $150 \mathrm{~min}$, glucose had to be infused in order to maintain plasma glucose at the hypoglycaemic values of the control study. In contrast to the control study in which both plasma NEFA and 3- $\beta$-hydroxybutyrate increased progressively after $240 \mathrm{~min}$ above baseline, in the blockade of ketogenesis study plasma NEFA and 3 - $\beta$-hydroxybutyrate concentrations remained suppressed until the end of the experiments $(0.09 \pm 0.02 \mathrm{mmol} / \mathrm{l}$ and $0.1 \pm 0.01$ $\mathrm{mmol} / \mathrm{l}$ at $480 \mathrm{~min}, \mathrm{NEFA}$ and $3-\beta$-hydroxybutyrate, respectively).

\section{Plasma glycerol, lactate and alanine concentrations (Table 1)}

Plasma glycerol showed the same pattern as NEFA and 3$\beta$-hydroxybutyrate. Plasma lactate was slightly, although not significantly greater in the blockade of ketogenesis studies $(1049 \pm 66 \mu \mathrm{mol} / \mathrm{l})$ than in the control studies $(867 \pm 81 \mu \mathrm{mol} / \mathrm{l})$. Plasma alanine decreased in both studies, but to a lesser extent in the blockade of ketogenesis study ( $p<0.05$ after $240 \mathrm{~min}$ ).

\section{Plasma counterregulatory hormones (Fig. 2)}

Plasma glucagon and epinephrine concentrations increased at $150 \mathrm{~min}$ (in response to a decrease in plasma glucose concentration to $3.7 \pm 0.1 \mathrm{mmol} / \mathrm{l})$, to a comparable extent in both studies $(p=N S)$. Plasma cortisol (at $180 \mathrm{~min}$, when plasma glucose was $3.5 \pm 0.11 \mathrm{mmol} / \mathrm{l}$ ) and plasma noradrenaline (at $300 \mathrm{~min}$, when plasma glucose was $3.2 \pm 0.1 \mathrm{mmol} / \mathrm{l}$ ) also increased similarly in both studies $(p=\mathrm{NS})$. The plasma growth hormone response was greater after 360 min in the blockade of ketogenesis study as compared to the control study $(1.04 \pm 0.05 \mathrm{pmol} / 1$ vs $0.29 \pm 0.05 \mathrm{pmol} / 1, p<0.05$ ).

Table 1. Plasma glycerol, lactate and alanine concentrations (mean \pm SEM) in the control study (I) and in the blockade of ketogenesis study (II)

\begin{tabular}{|c|c|c|c|c|c|c|c|c|c|c|c|c|c|c|c|c|c|c|c|}
\hline Time (min) & & -30 & 0 & 30 & 60 & 90 & 120 & 150 & 180 & 210 & 240 & 270 & 300 & 330 & 360 & 390 & 420 & 450 & 480 \\
\hline \multirow{2}{*}{$\begin{array}{l}\text { Plasma } \\
\text { glycerol } \\
(\mu \mathrm{mol} / \mathrm{l})\end{array}$} & I & $\begin{array}{r}85 \\
+14\end{array}$ & $\begin{array}{r}83 \\
\pm 13\end{array}$ & $\begin{array}{r}50 \\
\pm 6\end{array}$ & $\begin{array}{r}36 \\
\pm 5\end{array}$ & $\begin{array}{r}39 \\
\pm 5\end{array}$ & $\begin{array}{r}43 \\
\pm 7\end{array}$ & $\begin{array}{r}45 \\
\pm 8\end{array}$ & $\begin{array}{r}46 \\
\pm 6\end{array}$ & $\begin{array}{r}55 \\
\pm 9\end{array}$ & $\begin{array}{r}77 \\
+10\end{array}$ & $\begin{array}{r}85 \\
+11\end{array}$ & $\begin{array}{r}94 \\
\pm 9\end{array}$ & $\begin{array}{r}90 \\
\pm 12\end{array}$ & $\begin{array}{r}86 \\
\pm 14\end{array}$ & $\begin{array}{r}93 \\
\pm 12\end{array}$ & $\begin{array}{r}107 \\
\pm 12\end{array}$ & $\begin{array}{r}100 \\
\pm 13\end{array}$ & $\begin{array}{r}91 \\
\pm 12\end{array}$ \\
\hline & II & $\begin{array}{r}79 \\
+12\end{array}$ & $\begin{array}{r}77 \\
\pm 11\end{array}$ & $\begin{array}{r}53 \\
\pm 9\end{array}$ & $\begin{array}{r}40 \\
\pm 8\end{array}$ & $\begin{array}{r}35 \\
\pm 8\end{array}$ & $\begin{array}{r}42 \\
\pm 7\end{array}$ & $\begin{array}{r}43 \\
\pm 7\end{array}$ & $\begin{array}{r}50 \\
\pm 6\end{array}$ & $\begin{array}{r}42 \\
\pm 5\end{array}$ & $\begin{array}{r}42 \\
\pm 7\end{array}$ & $\begin{array}{r}40 \\
\pm 6\end{array}$ & $\begin{array}{r}36 \\
\pm 7\end{array}$ & $\begin{array}{r}41 \\
\pm 5\end{array}$ & $\begin{array}{r}48 \\
\pm 7\end{array}$ & $\begin{array}{r}45 \\
\pm 7\end{array}$ & $\begin{array}{r}48 \\
\pm 8\end{array}$ & $\begin{array}{r}52 \\
\pm 9\end{array}$ & $\begin{array}{r}57 \\
\pm 10\end{array}$ \\
\hline \multirow{2}{*}{$\begin{array}{l}\text { Plasma } \\
\text { lactate } \\
(\mu \mathrm{mol} / \mathrm{l})\end{array}$} & I & $\begin{array}{r}850 \\
\pm 100\end{array}$ & $\begin{array}{r}890 \\
\pm 110\end{array}$ & $\begin{array}{r}895 \\
\pm 80\end{array}$ & $\begin{array}{r}890 \\
\pm 89\end{array}$ & $\begin{array}{r}900 \\
\pm 91\end{array}$ & $\begin{array}{r}910 \\
\pm 110\end{array}$ & $\begin{array}{r}905 \\
\pm 120\end{array}$ & $\begin{array}{r}900 \\
\pm 111\end{array}$ & $\begin{array}{r}880 \\
\pm 93\end{array}$ & $\begin{array}{r}840 \\
\pm 99\end{array}$ & $\begin{array}{r}810 \\
\pm 100\end{array}$ & $\begin{array}{r}790 \\
\pm 101\end{array}$ & $\begin{array}{r}800 \\
\pm 103\end{array}$ & $\begin{array}{r}790 \\
\pm 102\end{array}$ & $\begin{array}{r}870 \\
\pm 99\end{array}$ & $\begin{array}{r}950 \\
+123\end{array}$ & $\begin{array}{r}910 \\
+132\end{array}$ & $\begin{array}{r}840 \\
+100\end{array}$ \\
\hline & II & $\begin{array}{r}900 \\
\pm 99\end{array}$ & $\begin{array}{r}890 \\
\pm 101\end{array}$ & $\begin{array}{r}920 \\
\pm 89\end{array}$ & $\begin{array}{r}940 \\
\pm 88\end{array}$ & $\begin{array}{r}1012 \\
\pm 98\end{array}$ & $\begin{array}{r}110 \\
\pm 89\end{array}$ & $\begin{array}{r}1125 \\
\pm 105\end{array}$ & $\begin{array}{r}1110 \\
\pm 91\end{array}$ & $\begin{array}{r}1145 \\
\pm 106\end{array}$ & $\begin{array}{r}1107 \\
\pm 94\end{array}$ & $\begin{array}{r}1145 \\
\pm 67\end{array}$ & $\begin{array}{r}1090 \\
\pm 89\end{array}$ & $\begin{array}{r}1034 \\
\pm 80\end{array}$ & $\begin{array}{r}1050 \\
\pm 77\end{array}$ & $\begin{array}{r}1025 \\
\pm 87\end{array}$ & $\begin{array}{l}1000 \\
\pm 98\end{array}$ & $\begin{array}{r}991 \\
\pm 103\end{array}$ & $\begin{array}{r}980 \\
\pm 86\end{array}$ \\
\hline \multirow{2}{*}{$\begin{array}{l}\text { Plasma } \\
\text { alanine } \\
\text { (umol/ })\end{array}$} & I & $\begin{array}{r}457 \\
\pm 44\end{array}$ & $\begin{array}{r}483 \\
\pm 56\end{array}$ & $\begin{array}{r}456 \\
\pm 51\end{array}$ & $\begin{array}{r}414 \\
\pm 39\end{array}$ & $\begin{array}{r}400 \\
\pm 37\end{array}$ & $\begin{array}{r}406 \\
\pm 35\end{array}$ & $\begin{array}{r}382 \\
\pm 37\end{array}$ & $\begin{array}{r}347 \\
\pm 32\end{array}$ & $\begin{array}{r}378 \\
\pm 40\end{array}$ & $\begin{array}{r}366 \\
\pm 37\end{array}$ & $\begin{array}{r}312 \\
\pm 31\end{array}$ & $\begin{array}{r}297 \\
\pm 29\end{array}$ & $\begin{array}{r}261 \\
\pm 41\end{array}$ & $\begin{array}{r}238 \\
\pm 25\end{array}$ & $\begin{array}{r}267 \\
\pm 27\end{array}$ & $\begin{array}{r}300 \\
\pm 40\end{array}$ & $\begin{array}{r}277 \\
\pm 27\end{array}$ & $\begin{array}{r}256 \\
\pm 45\end{array}$ \\
\hline & 11 & $\begin{array}{r}423 \\
\pm 29\end{array}$ & $\begin{array}{r}436 \\
+34\end{array}$ & $\begin{array}{r}439 \\
+36\end{array}$ & $\begin{array}{r}426 \\
\pm 33\end{array}$ & $\begin{array}{r}410 \\
+28\end{array}$ & $\begin{array}{r}400 \\
\pm 33\end{array}$ & $\begin{array}{r}423 \\
\pm 34\end{array}$ & $\begin{array}{r}392 \\
\pm 25\end{array}$ & $\begin{array}{r}389 \\
\pm 27\end{array}$ & $\begin{array}{r}392 \\
\pm 28\end{array}$ & $\begin{array}{r}378 \\
\pm 32\end{array}$ & $\begin{array}{r}345 \\
\pm 31\end{array}$ & $\begin{array}{r}303 \\
\pm 35\end{array}$ & $\begin{array}{r}389 \\
\pm 40\end{array}$ & $\begin{array}{r}306 \\
\pm 29\end{array}$ & $\begin{array}{r}345 \\
\pm 34\end{array}$ & $\begin{array}{r}300 \\
\pm 44\end{array}$ & $\begin{array}{r}291 \\
\pm 33\end{array}$ \\
\hline
\end{tabular}




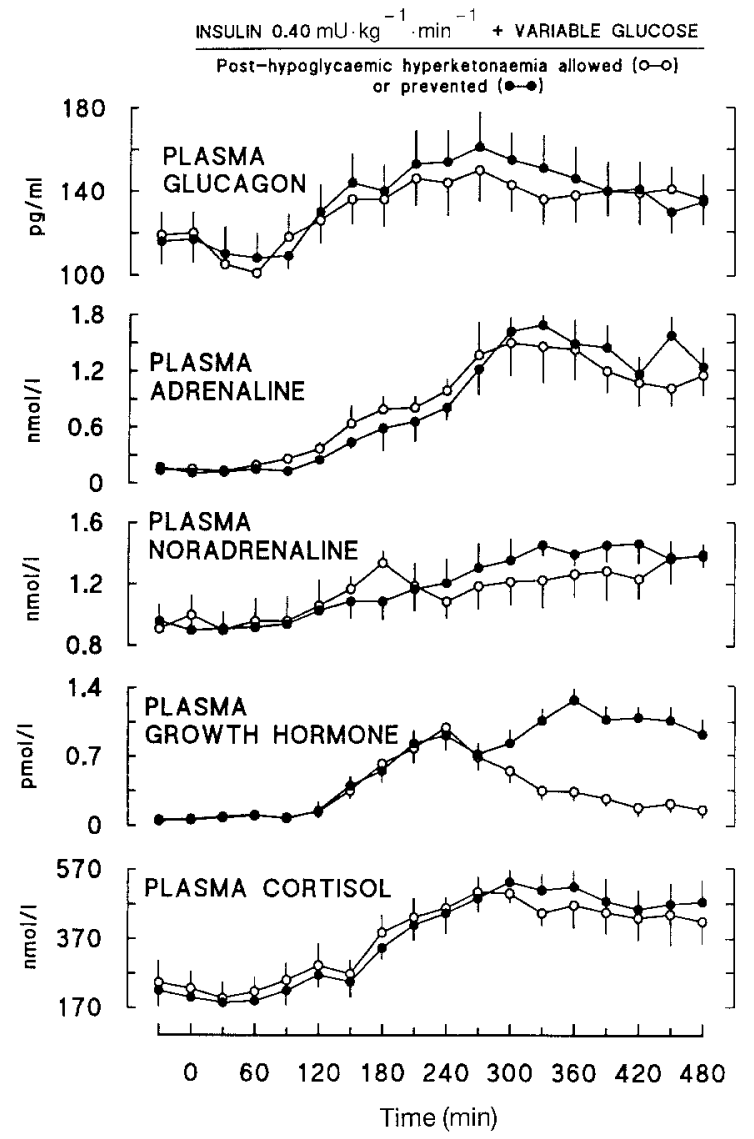

Fig. 2. Plasma counterregulatory hormone concentrations during insulin-induced hypoglycaemia in the control study $(O)$ and in the blockade of ketogenesis study $(\mathbf{0})$. Values shown are mean $\pm S E M$. $n=10$ normal subjects

Autonomic and neuroglycopenic symptoms and cognitive function (Table 2 and Fig. 3)

Autonomic and neuroglycopenic symptom scores increased to a similar extent in both studies after $330 \mathrm{~min}$ when plasma glucose concentration was $3.2 \pm 0.1 \mathrm{mmol} / 1$ (score autonomic symptoms $3.2 \pm 0.3$ and $3.3 \pm 0.4$; score neuroglycopenic symptoms $3.5 \pm 0.4$ and $3.2 \pm 0.4$, control and blockade of ketogenesis studies, respectively, $p=\mathrm{NS}$ ). Deterioration of cognitive function during hypoglycaemia was similar in the control study and in the blockade of ketogenesis study both in terms of individual cognitive tests (Table 2) as well as sum of z scores (Fig. 3) although it did not reach the statistical significance in either of the two studies.

\section{Glycaemic thresholds of responses of counterregulatory hormones and symptoms of hypoglycaemia (Table 3)}

Glycaemic thresholds of responses of counterregulatory hormones and symptoms (both autonomic and neuroglycopenic) to hypoglycaemia were similar in the control study and in the studies of blockade of ketogenesis $(p=\mathrm{NS})$.

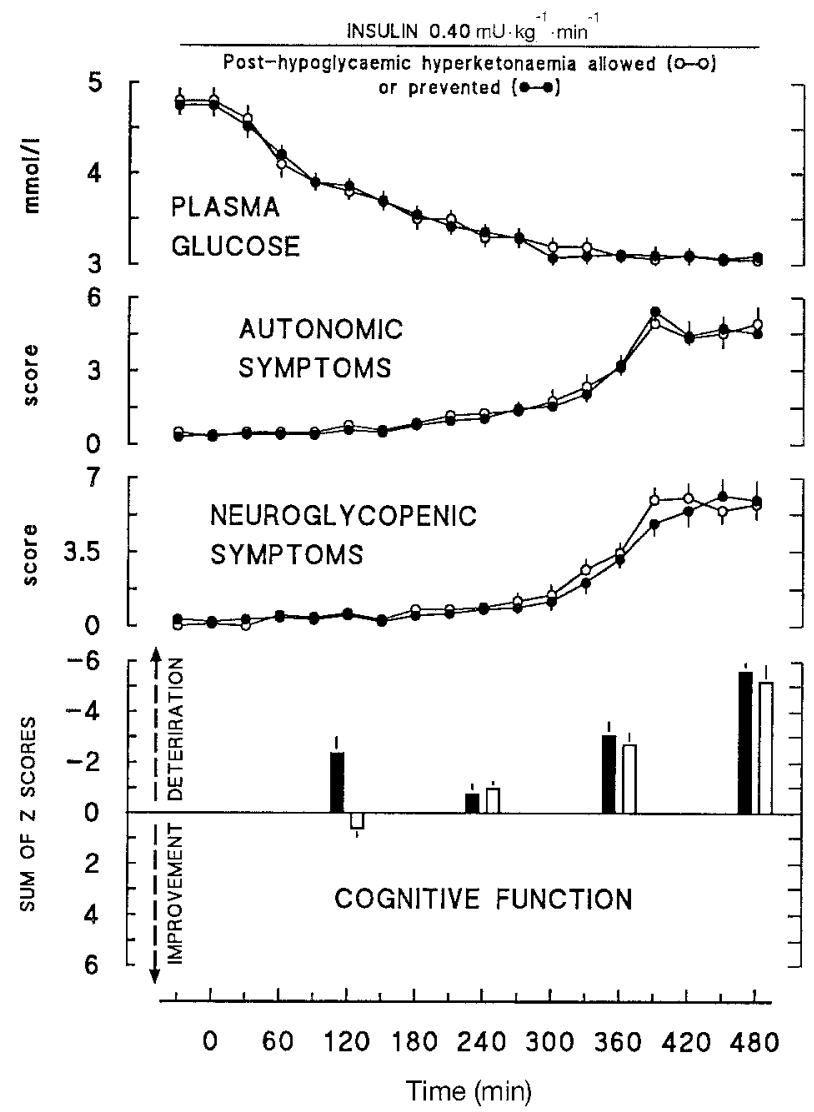

Fig.3. Autonomic and neuroglycopenic symptoms, and deterioration of cognitive function (sum of z scores of psychomotor tests) during insulin-induced hypoglycaemia in the control study (O) and blockade of ketogenesis study $(\bullet)$. Values shown are mean $\pm S E M$. $n=10$ normal subjects

\section{Discussion}

The present studies were designed to test the hypothesis that spontaneous hyperketonaemia following counterregulation of insulin-induced hypoglycaemia, might provide the brain with an alternative fuel, and protect brain function from neuroglycopenia. Our results indicate that neither the glycaemic thresholds, nor the overall responses of counterregulatory hormones and symptoms (both autonomic and neuroglycopenic), nor the deterioration of cognitive function during hypoglycaemia, worsen when spontaneous post-hypoglycaemic hyperketonaemia is prevented - the opposite results would be anticipated had ketones been able to substitute for glucose as oxidative fuel in the brain. Thus, the hypothesis that ketones can be used by the human brain as an alternative fuel for glucose following the onset of hypoglycaemia should be rejected, at least in physiological conditions mimicking the changes in plasma glucose and ketones observed in the clinical hypoglycaemia of patients with Type 1 (insulin-dependent) diabetes mellitus $[4,12,13]$.

Previous studies in humans addressing the issue of the use of alternative substrates during hypoglycaemia by the human brain have been based on an infusion of ketones, and have yielded conflicting results $[8,9]$. Frolund et al. [8] 
Table 2. Scores of cognitive test (mean \pm SEM) in the control study (I) and in the blockade of ketogenesis study (II)

\begin{tabular}{|c|c|c|c|c|c|c|}
\hline Time (min) & & 0 & 120 & 240 & 360 & 480 \\
\hline Backward span ${ }^{\mathrm{a}}$ & $\begin{array}{l}\text { I } \\
\text { II }\end{array}$ & $\begin{array}{l}6.1 \pm 0.3 \\
5.4 \pm 0.2\end{array}$ & $\begin{array}{l}6.2 \pm 0.2 \\
5.2 \pm 0.2\end{array}$ & $\begin{array}{l}6.0 \pm 0.4 \\
5.4 \pm 0.3\end{array}$ & $\begin{array}{l}5.7 \pm 0.3 \\
5.3 \pm 0.4\end{array}$ & $\begin{array}{l}5.4 \pm 0.3 \\
5.2 \pm 0.3\end{array}$ \\
\hline Forward span ${ }^{a}$ & $\begin{array}{l}\text { I } \\
\text { II }\end{array}$ & $\begin{array}{l}8.2 \pm 0.4 \\
7.0 \pm 0.3\end{array}$ & $\begin{array}{l}7.7 \pm 0.3 \\
6.7 \pm 0.3\end{array}$ & $\begin{array}{l}6.3 \pm 0.2 \\
6.9 \pm 0.3\end{array}$ & $\begin{array}{l}6.5 \pm 0.3 \\
6.6 \pm 0.4\end{array}$ & $\begin{array}{l}6.6 \pm 0.3 \\
6.5 \pm 0.3\end{array}$ \\
\hline Word list ${ }^{\mathrm{a}}$ & $\begin{array}{l}\text { I } \\
\text { II }\end{array}$ & $\begin{array}{l}4.2 \pm 0.3 \\
3.6 \pm 0.4\end{array}$ & $\begin{array}{l}4.8 \pm 0.4 \\
3.1 \pm 0.4\end{array}$ & $\begin{array}{l}3.2 \pm 0.3 \\
2.8 \pm 0.4\end{array}$ & $\begin{array}{l}3.0 \pm 0.3 \\
3.2 \pm 0.4\end{array}$ & $\begin{array}{l}3.1 \pm 0.3 \\
2.9 \pm 0.4\end{array}$ \\
\hline Simple RT ${ }^{b}$ & $\begin{array}{l}\text { I } \\
\text { II }\end{array}$ & $\begin{array}{l}270 \pm 16.3 \\
298 \pm 17.8\end{array}$ & $\begin{array}{l}291.2 \pm 19.2 \\
288.4 \pm 18.8\end{array}$ & $\begin{array}{l}318.2 \pm 18.2 \\
300.5 \pm 17.2\end{array}$ & $\begin{array}{l}316.7 \pm 21.2 \\
318.0 \pm 33.2\end{array}$ & $\begin{array}{l}318.2 \pm 23.2 \\
324.0 \pm 33.6\end{array}$ \\
\hline Word reading & $\begin{array}{l}\text { I } \\
\text { II }\end{array}$ & $\begin{array}{l}108.2 \pm 2.7 \\
105.4 \pm 3.0\end{array}$ & $\begin{array}{l}107.3 \pm 3.2 \\
105.4 \pm 4.6\end{array}$ & $\begin{array}{l}104.2 \pm 4.8 \\
105.6 \pm 5.5\end{array}$ & $\begin{array}{l}102.3 \pm 4.9 \\
101.4 \pm 5.4\end{array}$ & $\begin{array}{l}101.2 \pm 4.9 \\
100.4 \pm 5.4\end{array}$ \\
\hline Interference ${ }^{\mathrm{a}}$ & $\begin{array}{l}\text { I } \\
\text { II }\end{array}$ & $\begin{array}{l}46.2 \pm 1.7 \\
48.1 \pm 1.5\end{array}$ & $\begin{array}{l}46.8 \pm 1.7 \\
48.2 \pm 1.7\end{array}$ & $\begin{array}{l}47.8 \pm 2.0 \\
50.3 \pm 2.1\end{array}$ & $\begin{array}{l}46.2 \pm 1.9 \\
51.8 \pm 2.1\end{array}$ & $\begin{array}{l}45.7 \pm 2.2 \\
46.9 \pm 3.7\end{array}$ \\
\hline Trails $A^{c}$ & $\begin{array}{l}\text { I } \\
\text { II }\end{array}$ & $\begin{array}{l}59.3 \pm 5.9 \\
64.6 \pm 6.6\end{array}$ & $\begin{array}{l}60.2 \pm 6.8 \\
70.0 \pm 7.3\end{array}$ & $\begin{array}{l}72.2 \pm 6.9 \\
68.0 \pm 7.0\end{array}$ & $\begin{array}{l}71.1 \pm 6.4 \\
70.0 \pm 6.8\end{array}$ & $\begin{array}{l}71.3 \pm 6.3 \\
71.9 \pm 6.7\end{array}$ \\
\hline Trails $B^{c}$ & $\begin{array}{l}\text { I } \\
\text { II }\end{array}$ & $\begin{array}{l}68.2 \pm 6.3 \\
65.2 \pm 6.6\end{array}$ & $\begin{array}{l}71.2 \pm 7.1 \\
73.6 \pm 8.6\end{array}$ & $\begin{array}{l}68.2 \pm 7.3 \\
60.0 \pm 7.7\end{array}$ & $\begin{array}{l}72.2 \pm 7.8 \\
76.6 \pm 8.7\end{array}$ & $\begin{array}{l}74.2 \pm 7.4 \\
78.4 \pm 8.8\end{array}$ \\
\hline Vigilance $^{\mathrm{a}}$ & $\begin{array}{l}\text { I } \\
\text { II }\end{array}$ & $\begin{array}{l}47.2 \pm 3.0 \\
46.8 \pm 2.1\end{array}$ & $\begin{array}{l}47.0 \pm 2.8 \\
44.0 \pm 2.8\end{array}$ & $\begin{array}{l}45.6 \pm 2.8 \\
46.0 \pm 2.8\end{array}$ & $\begin{array}{l}46.2 \pm 2.7 \\
49.1 \pm 3.9\end{array}$ & $\begin{array}{l}45.9 \pm 2.7 \\
46.7 \pm 3.9\end{array}$ \\
\hline
\end{tabular}

${ }^{a}$ Number of responses, ${ }^{\mathrm{b}}$ Time in ms, ${ }^{\mathrm{c}}$ Time in s, RT, Reaction time

Table 3. Glycaemic thresholds of plasma counterregulatory hormone and symptom responses (mean $\pm S E M$ ) to hypoglycaemia in the control, and blockade of ketogenesis studies. Glycaemic thresholds were defined as the plasma glucose concentration (expressed in mmol/ $)$ at which the parameter first exceeded the $95 \%$ confidence limit observed for changes in that parameter at baseline (euglycaemia)

\begin{tabular}{lll}
\hline & Control study & $\begin{array}{l}\text { Blockade of ke- } \\
\text { togenesis study }\end{array}$ \\
\hline Glucagon & $3.6 \pm 0.1$ & $3.7 \pm 0.1$ \\
Adrenaline & $3.5 \pm 0.1$ & $3.6 \pm 0.1$ \\
Noradrenaline & $3.1 \pm 0.1$ & $3.2 \pm 0.1$ \\
Growth hormone & $3.6 \pm 0.1$ & $3.6 \pm 0.1$ \\
Cortisol & $3.5 \pm 0.1$ & $3.6 \pm 0.1$ \\
Autonomic symptoms & $3.1 \pm 0.1$ & $3.1 \pm 0.1$ \\
Neuroglycopenic symptoms & $3.0 \pm 0.1$ & $3.1 \pm 0.1$ \\
\hline
\end{tabular}

found no effects of a $\beta$-hydroxybutyrate infusion during acute hypoglycaemia. In contrast, Amiel et al. [9] reported that responses of plasma adrenaline, growth hormone and cortisol to hypoglycaemia, slowly induced over a 4-h period by infusion of both insulin and glucose, were reduced when $\beta$-hydroxybutyrate was also infused. A similar finding has recently been reported by Veneman et al. [22].

To the best of our knowledge, the present study is the first to address the question of the possible effect on human brain metabolism of the spontaneous, i.e. physiologic rebound increase in endogenous plasma ketones after onset of counterregulation of hypoglycaemia. Not- ably, the conclusions of the present studies, i.e. that ketones are not a brain fuel during hypoglycaemia, are opposite to those of Amiel et al. [9] and Veneman et al. [22]. However, in the studies of Amiel et al. [9] and Veneman et al. [22], the infusion of $\beta$-hydroxybutyrate was initiated approximately $1-2 \mathrm{~h}$ before plasma glucose decreased below the glycaemic threshold for release of adrenaline, and was continued throughout. Thus, in the studies of Amiel et al. [9] and Veneman et al. [22] hyperketonaemia preceded by at least $1-2 \mathrm{~h}$ the onset of hypoglycaemia, whereas in the present study, endogenous hyperketonaemia followed the onset of hypoglycaemia by approximately $2 \mathrm{~h}$. It is likely that in the study of Amiel et al. [9], the 10-fold increase in plasma ketone body concentration (plasma $\beta$-hydroxybutyrate from $\approx 0.06 \mathrm{mmol} / 1$ to $\approx 0.6 \mathrm{mmol} / \mathrm{l}$ ) during the $2 \mathrm{~h}$ prior to the onset of hypoglycaemia induced brain utilization of ketones, so that during the ensuing hypoglycaemia the brain continued to use ketones. This would support the concept of a lag phase required by the brain to adapt its metabolism to ketones [5]. In fact, previous studies have indicated that only after a prolonged fast do endogenous ketones become an important fuel for brain metabolism in the post-absorptive state [5] and during insulin-induced hypoglycaemia [23, 24]. What the studies of Amiel et al. [9] and Veneman et al. [22] seem to indicate in this regard, is that a relatively short period of time, i. e. approximately $1-2 \mathrm{~h}$ of hyperketonaemia are sufficient to induce cerebral utilization of ketones. Interestingly, in the present studies the plasma concentration of $\beta$-hydroxybutyrate after onset of counterregulation to hypoglycaemia, was nearly twice as 
high as compared to that in the studies of Amiel et al. [9], but we found no evidence for brain utilization of ketones. Thus, it appears that the timing of increase in plasma ketones as compared to the onset of hypoglycaemia, more than the absolute plasma ketone concentration achieved, is the critical factor for utilization of ketones by the brain. A similar effect of timing of plasma increase in a substrate, has been reported to be important in conditions of metabolic competition between glucose and NEFA for oxidation at the muscle level [25].

The present studies do not exclude that ketones cannot be used by the brain under special experimental conditions. It is well known that the necessary enzymes for ketone oxidation are present in the brain [26], and that the transport of ketones through the blood-brain barrier via transporters of monocarboxylic acids is linearly related to arterial concentrations of ketones [27]. Experiments in animals indicate that ketones may be rapidly used by the brain. For example, intraperitoneal injection of acetate in the mouse [28], or infusion of $\beta$-hydroxybutyrate in the rat [7] reduce the signs of hypoglycaemia, and infusion of ketones in dogs leads to increased brain utilization of ketones and reduced counterregulatory response to hypoglycaemia [6]. However, the present studies indicate that the human brain cannot utilize ketones when they become available after onset of neuroglycopenia, i. e. in conditions closely mimicking the clinical hypoglycaemia of patients with Type 1 diabetes $[12,13]$ and insulinoma [29]. Thus, the fact that the human brain may partially replace glucose with ketones as fuel when exogenous ketones are infused before the onset of neuroglycopenia $[9,22]$ is interesting, but not relevant to the clinical situation of hypoglycaemia in which plasma ketones are initially suppressed and later increase [4].

The metabolic effects of administration of acipimox in the present studies should be noted. First, acipimox effectively blocked lipolysis, as previously reported [10]. That ketogenesis remained blocked despite increases in plasma of several ketogenetic, counterregulatory hormones, reaffirms the key role of the substrate NEFA in promoting ketogenesis [30]. Secondly, glucose had to be infused when lipolysis and ketogenesis were blocked to maintain plasma glucose at the values of the control study. In theory, this might be due to reduced secretion of counterregulatory hormones, secondary to loss of compensation of brain metabolism by ketones, or to impaired counterregulation. The fact that counterregulatory hormones, with the exception of growth hormone, were superimposable in the two studies, and the recent demonstration of the importance of lipolysis in counterregulation [10], indicates that the latter, not the former factor accounted for the need of glucose infusion. The growth hormone responses in the blockade of ketogenesis study were exaggerated as compared to the control study. This was most likely due to the well-known suppressive effects of NEFA on growth hormone release, as previously reported $[10,19]$.

Finally, one could argue whether it would be teleologically advantageous for the brain to use ketones during neuroglycopenia. In theory, if the brain could acutely use ketones during hypoglycaemia, then the glycaemic thresholds of counterregulatory hormones and symptoms in response to hypoglycaemia would increase, i. e. greater decreases in blood glucose would be required to elicit a response, or maximal responses of hormones and symptoms to hypoglycaemia would be blunted, or both, as reported by Veneman et al. [22]. These higher glycaemic thresholds or decreased maximal responses, or both, would represent a serious threat to the safety of the brain and whole body, because ketones would only partially, not fully compensate for neuroglycopenia, as indicated by the studies of Amiel et al. [9] and Veneman et al. [22]. Therefore, if the brain used ketones during hypoglycaemia, the responses of counterregulatory hormones would be reduced, and the symptoms of neuroglycopenia would be masked, resulting in a clinical picture qualitatively similar to that of the hypoglycaemia unawareness of Type 1 diabetic patients [31]. Thus, to protect itself it is better that the brain does not use ketones during clinical hypoglycaemia.

Acknowledgements. The excellent technical assistance of $\mathrm{Mr}$. G. Cipiciani, the careful editorial help of Ms. P.Boyce, and the friendly support from the community of Kreuzberg Pass and Fischleintal, Hochpustertal, are gratefully acknowledged. This work was supported by the Consiglio Nazionale delle Ricerche (C.N.R. grant 90.02412.CT04 and finalized project "Aging" grant 91.00325.PF4O); and the Juvenile Diabetes Foundation (Grant 193108).

\section{References}

1. Mitrakou A, Ryan C, Veneman T et al. (1991) Hierarchy of glycemic thresholds for counterregulatory hormone secretion, symptoms, and cerebral dysfunction. Am J Physiol 260:E67-E74

2. Pardridge WM (1983) Brain metabolism: a perspective from the blood-brain barrier. Physiol Rev 63: 1481-1535

3. Cryer P, Gerich J (1985) Glucose counterregulation, hypoglycemia and intensive insulin therapy of diabetes mellitus. $\mathrm{N}$ Engl J Med 313: 232-241

4. De Feo P, Perriello G, De Cosmo S et al. (1986) Comparison of glucose counterregulation during short-term and prolonged hypoglycemia in normal humans. Diabetes 35: 563-569

5. Owen OE, Morgan AP, Kemp HG et al. (1967) Brain metabolism during fasting. J Clin Invest 46: 1590-1595

6. Flatt JP, Blackburn GL, Randers G, Stanbury JB (1974) Effects of ketone body infusion on hypoglycemic reaction in postabsorptive state in dogs. Metab Clin Exp 23: 151-158

7. Stricker HM, Rowland N, Saller CF, Friedman MI (1977) Homeostasis during hypoglycemia: central control of adrenal secretion and peripheral control of feeding. Science 196: 79-81

8. Frolund J, Kerult H, Christiansen NJ, Alberti KGMM (1980) Effect of ketone body infusion on plasma catecholamine and substrate concentrations during acute hypoglycemia in man. J Clin Endocrinol Metab 50: 557-561

9. Amiel AS, Archibald HR, Chusney G, Williams AJK, Gale EAM (1991) Ketone infusion lowers hormonal responses to hypoglycaemia: evidence for acute cerebral utilization of a non-glucose fuel. Clin Sci 81: 189-194

10. Fanelli C, Calderone S, Epifano Let al. (1993) Demonstration of a critical role for FFA in mediating counterregulatory stimulation of gluconeogenesis and suppression of glucose utilization in man. J Clin Invest (in press)

11. McGuire E, Helderman J, Tobin R, Andres R, Berman M (1976) Effects of arterial versus venous sampling on analysis of glucose kinetics in man. J Appl Physiol 41: 565-573

12. Bolli GB, Dimitriadis GD, Pehling GB et al. (1984) Abnormal glucose counterregulation after subcutaneous insulin in insulindependent diabetes mellitus. N Engl J Med 310: 1706-1711 
13. Bolli GB, Gottesman IS, Campbell PJ, Haymond MW, Cryer PE, Gerich JE (1984) Glucose counterregulation and waning of insulin in the Somogyi phenomenon (posthypoglycemic hyperglycemia). N Engl J Med 311: 1214-1219

14. Bendtson I, Kverneland A, Pramming S, Binder C (1988) Incidence of nocturnal hypoglycemia in insulin-dependent diabetic patients on intensive therapy. Acta Med Scand 223: 543-548

15. Bending JJ, Pickup JC, Collins ACG, Keen H (1985) Rarity of a marked "dawn phenomenon" in diabetic subjects treated by continuous subcutaneous insulin infusion. Diabetes Care 8:28-33

16. Schwartz N, Clutter W, Shah S, Cryer P (1987) Glycemic thresholds for activation of glucose counterregulatory systems are higher than the thresholds for symptoms. J Clin Invest 79: $777-$ 781

17. De Feo P, Gallai V, Mazzotta G et al. (1988) Modest decrements in plasma glucose concentration cause early impairment in cognitive function and later activation of glucose counterregulation in the absence of hypoglycemic symptoms in normal man. J Clin Invest 82: 436-444

18. Boyle P, Schwartz N, Shah S et al. (1988) Plasma glucose concentrations at the onset of hypoglycemic symptoms in patients with poorly controlled diabetes and in nondiabetics. N Engl J Med 318: 1487-1492

19. Fanelli C, De Feo P, Porcellati F et al. (1992) Adrenergic mechanisms contribute to the late phase of hypoglycemic glucose counterregulation in humans by stimulating lipolysis. J Clin Invest 89: 2005-2013

20. Lowry O, Passonneau J (1972) Typical fluorimetric procedures for metabolite assays. In: Lowry O, Passonneau J (eds) A flexible system for enzymatic analysis. Academic Press, New York, pp $89-92$

21. Zar J (1984) Biostatistical analysis. Prentice Hall, Inc., Englewood Cliffs, pp $168-260$

22. Veneman T, Mitrakou A, Mokan M (1993) Mechanism for reduced awareness and counterregulatory hormone responses to hypoglycemia after fasting. Diabetes 42 [Suppl 1]: $45 \mathrm{~A}$
23. Drenick EJ, Alvarez LC, Tamasi GC, Brinckman AS (1972) Resistance to symptomatic insulin reactions after fasting. J Clin Invest $51: 2757-2762$

24. Adamson U, Lins P-E, Grill V (1989) Fasting for 72 h decreases the responses of counterregulatory hormones to insulin-induced hypoglycaemia in normal man. Scand J Clin Lab Invest 49: 751-756

25. Bonadonna R, Zych K, Boni C, Ferrannini E, De Fronzo RA (1989) Time dependence of the interaction between lipid and glucose in humans. Am J Physiol 257:E49-E56

26. Page MA, Williamson DH (1971) Enzymes of ketone body utilization in human brain. Lancet II: 66-69

27. Robinson AM, Williamson DH (1980) Physiological roles of ketone bodies as substrates and signals in mammalian tissues. Physiol Rev 60: 143-187

28. Urion D, Vremen HJ, Weiner MW (1979) Effect of acetate on hypoglycemic seizures in mice. Diabetes 28: 1022-1026

29. Rizza R, Haymond M, Verdonk C et al. (1981) Pathogenesis of hypoglycemia in insulinoma patients: suppression of hepatic glucose production by insulin. Diabetes 30: 377-381

30. Miles J, Haymond MW, Nissen SL, Gerich JE (1983) Effects of free fatty acid availability, glucagon excess, and insulin deficiency on ketone body production in postabsorptive man. J Clin Invest 71: 1554-1561

31. Gerich JE, Mokan M, Veneman T, Korytkowski M, Mitrakou A (1991) Hypoglycemia unawareness. Endocr Rev 12: 356-371

Received: 22 April 1993

and in revised form: 15 June 1993

Professor G.B. Bolli

Dipartimento di Medicina Interna

e Scienze Endocrine e Metaboliche

Via E. Dal Pozzo

I-06126 Perugia

Italy 